\title{
TELJESÍTMÉNYMÉRÉS A KÖZÚTON
}

\section{Csipkés Margit - Nagy Lajos - Nagy Orsolya Bernadett}

Absztrakt: Az ellátási lánc működéséhez elengedhetetlen a megfelelő áruszállítás kialakítása, mivel az áruszállítást végzők kötik össze a lánc szereplöit és hoznak létre ezzel logisztikai láncokat. Cikkünkben a szállításhoz kapcsolódó olyan mutatószámokat mutatunk be, melyek nélkülözhetetlenek a döntési folyamatokban. Minden szállításnál fő célként kell kitüzni, hogy az alapanyag a termelöüzembe, illetve, hogy az elkészített termék a fogyasztóhoz jusson el minél rövidebb idő alatt, minél kisebb költség felhasználásával. Anyagunkban a magyarországi árutovábbítás leggyakrabban használt formáját a közúti szállítást/szállítmányozást/fuvarozást választottuk. Ennek oka, hogy a legtöbb általunk vizsgált szervezet napjainkban is legnagyobb hányadban ezt a formát alkalmazza (mind a hazai, mind a nemzetközi szállításnál is). Anyagunkban kitérünk a szállításnál használható teljesítménymérési mutatókra is (átfutási idővel, illetve a minőséggel kapcsolatos mutatókra).

\begin{abstract}
The supply chain function is essential for the proper delivery of goods design, since the goods connected to the chain actors and create this logistics chains. In our article the transport related indicators are presented, which are essential to the decision-making process in. Every delivery the main aim must be the basic material for the production plant, and that the reconstituted product to the consumer gets the shorter the time, the less cost of using. In our material the most commonly used form of transportation in Hungary was selected by road transportation, freight forwarding and transport (both for domestic and international transport). The reason for this is that most of our test organization today largest share in this form will apply. Materials we cover the transport to use performance measurement indicators too (lead time, and quality-related indicators).
\end{abstract}

Kulcsszavak: közúti szállítás, teljesítmény, logisztika, forgalomszervezés

Keywords: road transport, power, logistics, traffic organization

\section{Bevezetés}

A szállítás szervezés megismerése elött fontosnak tartottuk, hogy bemutassuk röviden, hogy az egyes alapfogalmak a témával kapcsolatban mit is jelentenek. Az árutovábbítást végre lehet hajtani szállítással, szállítmányozással és fuvarozással is. A szállítás esetén a termelő raktárából a vevőhöz jut az áru úgy, hogy az árutovábbítást a termelők vagy a felhasználók saját eszközükkel végzik, ahol nincs díjazása a továbbításnak. Ezzel szemben a fuvarozáskor az eladó, vagy a vevő, mint fuvaroztatók közbeiktatnak egy vállalkozót, aki az áru továbbítását elvégzi helyettük, és a fuvarozáskor a fuvarozási szerződés alapján, a fuvarozó a küldemény rendeltetési helyére történő továbbításra és a címzettnek történő kiszolgáltatására, a feladó díj fizetésére is köteles. Ezen díjfizetés miatt is mondják, hogy ez egy díjazás ellenében végzett árutovábbítást. A harmadik árutovábbítási lehetőség a szállítmányozás, mely az árutovábbítás szervezése, irányítása más fuvareszközével, általában hosszabb távú, bonyolult, több közlekedési ágazatot is igénybe vevő árutovábbítás, amely szolgáltatást a szállítmányozó nyújtja (Körmendi-Pucsek, 2008).

Az árutovábbításhoz az úgynevezett fuvarozási ágakat használhatjuk (vasúti, közúti, légi, tengeri, folyami (belvízi), csővezetékes fuvarozás). Minden fuvarozási ágnak meg van az előnye és a hátránya is. Ezek kiválasztásánál figyelembe kell venni 
az áru jellegét, rendeltetési helyet, fuvarozás idejét, költségét, az áru csomagolását, terjedelmét, az áruval kapcsolatos kárveszélyeket. A továbbiakban mi csak a közúti árufuvarozással foglalkozunk, mely elsősorban rövid távú forgalomban gazdaságos, azonban számos előnye miatt a távolsági forgalomban is előszeretettel alkalmazzák. A következőkben a forgalomszervezés különböző módozatait tekintjük át.

\section{A forgalomszervezési megoldások}

A forgalomszervezési megoldások az áruk helyváltoztatását megvalósító elemek, az áruszállító jármüvek és a szállítási igényektől függően lehetnek közvetlen, vonali, gyüjtő és elosztó forgalomban közlekedtetve. Ezek lehetnek továbbá egyszerü járatok, ingajáratok, illetve körjáratok is.

Közvetlen forgalomról (1. ábra) akkor beszélünk, ha a feladott árut a feladási és a rendeltetési állomás között ugyanabban a szállítójármüben továbbítják és a szállítás közben a jármü rakománya nem változik. Ebben az esetben teljes kocsirakományról beszélünk, attól függetlenül, hogy a feladó kihasználja e, a teljes gépjármű kapacitását.

\section{1. ábra: A közvetlen forgalom általános ábrázolása}

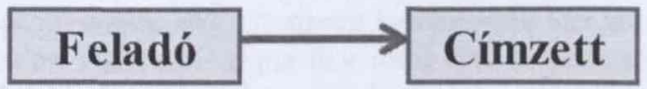

Forrás: Saját szerkesztés Halászné (1998) alapján

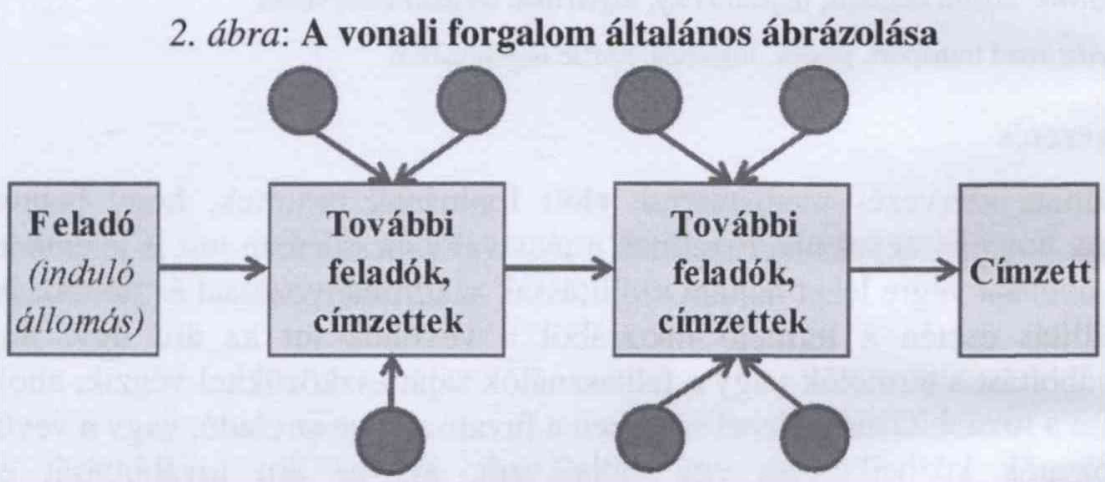

Forrás: Saját szerkesztés Halászné (1998) alapján

A vonali forgalom (2. ábra) esetén a szállítójármủ változatlan marad a szállítás folyamán, de bizonyos közbenső állomásokon (újabb feladó, pályaudvar, raktár stb.), újabb küldeményeket adnak fel, illetve adnak le.

A gyüjtő forgalom (3. ábra) közben csak újabb küldemények feladására van lehetőség, míg az elosztó forgalomban csak küldeményeket adnak le. Általában ezekben a forgalomszervezési megoldásokban a kezdő- és a végpont megegyezik. 


\section{3. ábra: A gyüjtő és elosztó forgalom általános ábrázolása}

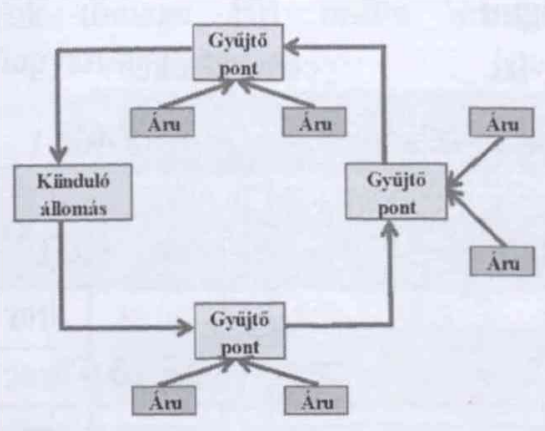

GYÜJTÓ forgalom

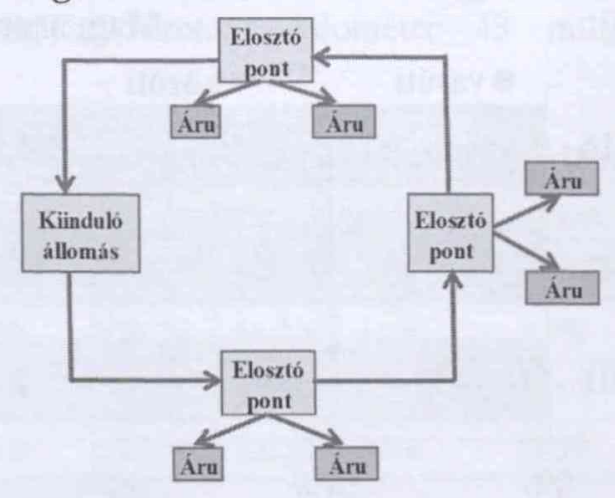

ELOSZTÓ forgalom

Forrás: Saját szerkesztés Halászné (1998) alapján

Beszélhetünk közvetlen és összetett szállítási láncról is (Halászné, 1998). A közvetlen, egytagú szállítás esetében a szállítást egy szállítójárművel, azonos szállítási pályán, átrakás nélkül végzik. Ezzel szemben az összetett, többtagú szállítás esetén több szállítójárművel, különböző szállítópályákon hajtják végre a szállítást, általában több szállítási ágazattal. Erre két megoldás is lehetséges. $\mathrm{Az}$ egyik a hagyományos megoldás, amikor csak az árukat, az egységrakományokat rakják egyik szállítójármüből a másikba. A másik lehetőség a kombinált szállítás, amikor az árut tartalmazó konténert, vagy magát a szállítójárművet rakják be, illetve át az egyik szállítójármüből a másikba.

\section{3. Áruszállítás alakulása Magyarországon}

Az adatok áttekintését követően megállapítottuk, hogy a belföldi áruszállítás döntő nagyságát (85\%-át 2016-ban) a közúti szállítás teszi ki. A szállított áruk tömege 2001-ben még csak 152 millió tonna volt, addig 2010-re 25\%-os növekedés következett be a 2001- évhez képest (190 millió tonna). Mára a 2001. évhez képest csak $21 \%$-os növekedéssel lehet kalkulálni.

Abban az esetben, ha az árutonna kilométerek alapján vizsgáljuk meg az elmúlt év áruszállításait, akkor megállapíthatjuk, hogy a vasúti és a csővezetékes szállításnak valóban nagyobb részaránya van a szállításban. Az árutonna-kilométer kifejezése alatt az elszállított áruk tömegének és a szállítási távolságnak a szorzatát értjük. Azaz egy árutonna-kilométer azt jelenti, hogy 1 tonna árunak 1 km-re történő elszállítását végezzük el. Az árutonna-kilométer teljesítményt fuvaronként kell kiszámítani a szállított áru tömege és a hozzátartozó kilométer összeszorzásával (esetenként a megfelelő díjszabási kilométer-távolság középértékével), és az így kapott árutonnakilométer adatokat kell összegezni egy évre vonatkozóan. 
4. ábra: A belföldi áruszállítás alakulása szállított áruk tömege alapján Magyarországon

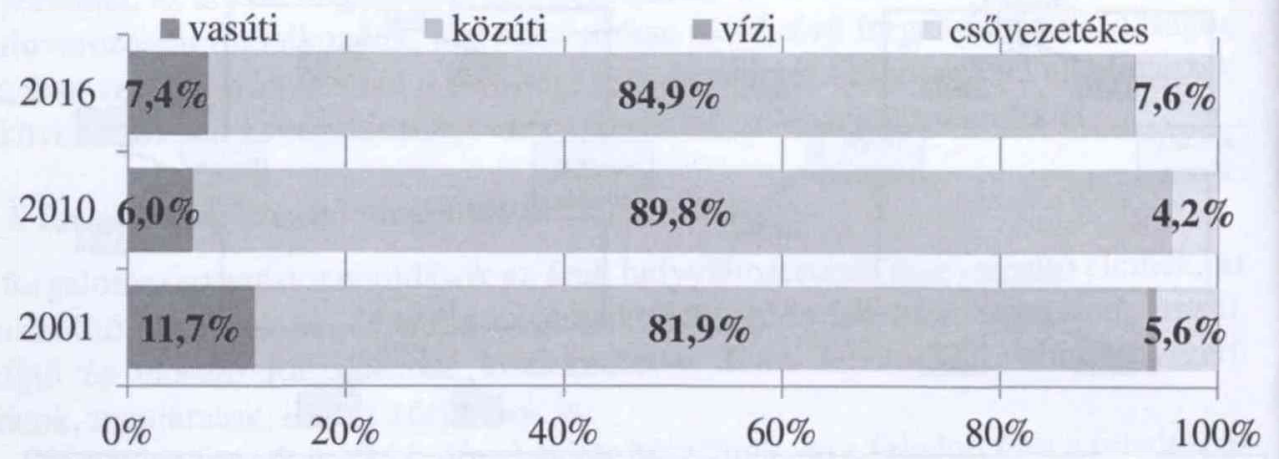

Forrás: Saját kalkuláció

Ez alapján történő összehasonlítás sokkal jobban mutatja az egyes ágazatok jelentőségét. A közúti áruszállítás részaránya így csak 70-80\% körül van. Míg 2001ben 10 milliárd, addig 2016-ra 15 milliárd árutonna kilométer volt a belföldi áruszállítás.

\section{5. ábra: A belföldi áruszállítás alakulása árutonna kilométer alapján Magyarországon}

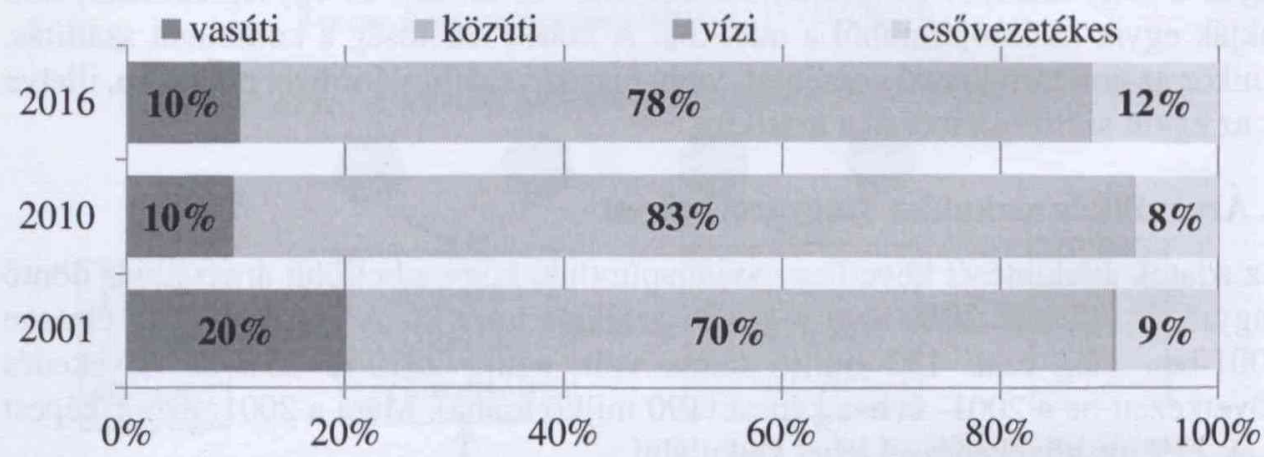

Forrás: Saját kalkuláció

A nemzetközi áruszállításokat áttekintve megállapítható, hogy egy koncentráltabb megoszlás van. Szállított áruk tömege alapján 2001-ben a vasút volt a vezető pozícióban, azonban mára jelentősége majdnem 20 százalékponttal csökkent. Ennek oka az eszközök és a vasúti pályák elöregedése. Jó hírnek tekinthető, hogy 2019-ig a Magyarországi összes vasúti hálózatot, és a hozzá tartozó elemeket fel fogják újítani a kormány elmondása szerint. A felújítások már 2016. év nyarán elkezdődtek, nagyobb szakaszok már felújított állapotban müködnek.

A szállított áruk tömegének megközelítőleg két ötödét közúton, míg kevesebb, mint egy ötödét csővezetéken. A vízi szállítás minimálisnak tekinthető jelenleg.

Az árutonna-kilométer alapján a közútnak még nagyobb jelentősége van, mivel az elszállított áruk majdnem kétharmada ezen az eszközön történt. A vízi szállítás és 
a csővezetékes szállítás jelentősége így még kisebb. A 2016. évben így a szállított áruk tömege 101 millió tonna, míg az árutonna-kilométer 43 milliárd Magyarországon.

1. táblázat: A nemzetközi áruszállítás összehasonlítása az elmúlt 15 évben

\begin{tabular}{|c|c|c|c|c|c|c|c|c|}
\hline \multirow{2}{*}{ Év } & \multicolumn{3}{|c|}{ Szállított áruk tömegének megoszlása } & \multicolumn{3}{|c|}{ Árutonna- kilométer megoszlása } \\
\cline { 2 - 9 } & vasúti & közúti & vízi & csővezetékes & vasúti & közúti & vízi & csỏvezetékes \\
\hline $\mathbf{2 0 1 6}$ & $36,0 \%$ & $40,6 \%$ & $7,9 \%$ & $15,4 \%$ & $20,7 \%$ & $65,2 \%$ & $4,6 \%$ & $9,4 \%$ \\
\hline $\mathbf{2 0 1 0}$ & $38,5 \%$ & $32,0 \%$ & $11,1 \%$ & $18,4 \%$ & $20,2 \%$ & $60,8 \%$ & $6,5 \%$ & $12,4 \%$ \\
\hline $\mathbf{2 0 0 1}$ & $59,3 \%$ & $9,2 \%$ & $3,0 \%$ & $28,4 \%$ & $35,0 \%$ & $34,3 \%$ & $6,2 \%$ & $24,2 \%$ \\
\hline
\end{tabular}

Forrás: Saját adatgyüjtés

A KSH legfrissebb adatai alapján 2017. II. félévében az áruszállítás teljesítménye 14,9 milliárd árutonna-kilométer volt, mely 0,8 százalékkal emelkedett a 2016. II. félévéhez viszonyítva. Növekedés figyelhető meg a csővezetékes szállításnál (16\%-kal), illetve a belvízi és a vasúti (13\%-kal) szállításnál. Ezzel ellentétben a közúti szállításnál csökkenés következett be 4,5\%-kal. Az összteljesítményt tekintve az áruszállításnál a közúti $67 \%$-ot, a vasúti $18 \%$-ot, a csővezetékes $11 \%$-ot, míg a belvízi szállítás 3,7\%-ot tett ki.

A magyar áruszállítás áttekintését követően a nemzetközi áruszállítást is áttekintettem, ahol megállapítottam, hogy a nemzetközi áruszállítás 2017 II. negyedévében $6,4 \%$-kal meghaladta a 2016. év II. negyedévét, míg árutonnakilométerben mért teljesítménye alapján csak egy $0,3 \%$-kos csökkenés figyelhető meg. A belföldi szállítást vizsgálva egy $6,5 \%$-os visszaesést, illetve egy $4,1 \%$-os növekedést tapasztaltunk. Összefüggések áttekintését követen megállapítottam, hogy 2017. I. félévben a szállított áruk tömege csak kismértékben változott $(+0,4 \%)$ a 2016. év ugyanezen időszakához képest.

Az áruszállítás teljesítménye a közúti fuvarozás átlagos szállítási távolságának növekedésének hatására 3,1\%-kal bővült 2016 I. félévéhez képest. A közúti áruszállítás árutonna-kilométerben mért teljesítménye 2017. évre 10,0 milliárd árutonna-kilométer volt, míg ebben a belföldi viszonylaté $0,6 \%$-kal emelkedett a 2016. II. negyedévihez képest. Mennyiségét tekintve 48 millió tonna árut szállítottak, mely azt jelentette, hogy a nemzetközi viszonylatban 4,7\%-kal kevesebb tömegü árut mozgattak.

\section{Szállítási teljesítményekről általában}

A magyarországi közúti áruszállítás áttekintését követően a szállítás teljesítményét szeretnénk bemutatni. A szakirodalmi feldolgozásból megállapítható, hogy a közlekedés feladata a helyváltoztatás lebonyolítása, a gazdaság és a társadalom ilyen jellegü igényeinek kielégítése. Természetesen az áru a helyét csak valamilyen közlekedési eszköz segítségével tudja elhagyni, azaz fuvarigény alakul ki. Ez azt jelenti, hogy meghatározott áruvolumen továbbítását kell valamilyen eszközzel 
elvégezni. A szállítás teljesítménye azonban ugyanazon volumen esetében is lényegesen eltérő lehet attól függően, hogy az árumennyiséget milyen távolságra kell elszállítani. A teljesítmény nagysága függ a volumen-igénytől, a szállítások távolságától és valamilyen formában az időjárástól. Ezen három paraméter figyelembe vétele mellett lehet a közlekedésben a szállítási teljesítményeket mérni. Ezt a szállítási teljesítményt tekintjük a közlekedés hasznos teljesítményének. A hasznos kifejezés mind a szállíttató, mind a szolgáltató részére fontos kifejezés. A közlekedési szolgáltató számára azért nagyon fontos, mivel ez alapján határozza meg tevékenységének díját, azaz bevételei a szállítási teljesítményekhez kötődnek.

Természetesen a szállítási teljesítmények mérőszámai közlekedési alágazatonként különbözőek, azonban minden alágazat esetén a következőket vesszük figyelembe:

- az áruszállítási volument vagy tömeget (Q) (tömeget),

- szállítási távolságot (S).

Ezen adatok ismeretében alakul ki a korábban említett árunonna-kilométer $(\mathrm{T}=\mathrm{Q} * \mathrm{~S})$.

A távolságokat a konkrét szállítások ténylegesen megtett (valós) úthosszával, vagy a díjszabási távolsággal vesszük figyelembe.

A közlekedési statisztika a szállítási teljesítményeket különböző részletezések szerint tartja nyilván. Ilyenek:

- Fizető (ezen belül teljes árú és kedvezményes) és nem fizető (ingyenes, önkezelési);

- Belföldi (helyi, távolsági) és nemzetközi (kimenő, bejövő, tranzit);

- Árunemenkénti (statisztikai besorolás szerint);

Nemzetgazdasági szinten a lebonyolító szervezet jellege (közforgalmú, nem közforgalmú, egyéni) szerinti bontásban kimutatott teljesítmények.

\section{A közúti áruszállítás üzemi és szolgáltatási színvonalának mérőszámai}

A közúti áruszállítást végző vállalatokat jellemző mutatószámok egyik csoportját az üzemtani mutatószámok alkotják, melyek a rendelkezésre álló gépjármúparkot, annak teljesítőképességét jellemzik. Másik csoportba a szolgáltatás színvonalát jellemző mutatószámok tartoznak, melyek azt vizsgálják, hogy a vállalat a rendelkezésre álló erőforrásait milyen eredménnyel hasznosította céljai elérésében.

A szállítási szolgáltatás színvonalát jellemezhetjük a tevékenység felépítésével, a szállítási volumennel, illetve a jármúvek számával. A teljesítményt mutatják az erőforrás felhasználás és a termelékenységet jellemző mutatószámok, mint például a szállítókapacitás kihasználtsága. A logisztikai teljesítményt tükrözheti továbbá a normák és a tényleges teljesítmények viszonya, mint a szállítási idő, illetve a határidők betartása. Ebbe a körbe tartozik a vállalat gépjármüparkjában lévő jármű típusok száma.

Egy jármücsoportban a jármüveket egy meghatározott tulajdonságuk szerint csoportosíthatjuk, mint például a szállítóképességük, mely a jármü számára a megengedett, vagy szerkezeti felépítéséből adódóan, a maximálisan elszállítható mennyiséget mutatja meg. Ez lehet a raksúly, illetve a raktérfogat. 
Vizsgálhatjuk még a járműveket üzemi állapotuk (4. ábra) szempontjából is. Itt megkülönböztetünk üzemben lévő és üzemen kívüli járműveket. Üzemben van a jármủ, ha az a vizsgált időszak alatt üzemképes és a szállítási feladatokra igénybe vehető. Üzemen kívül van a jármü, ha azt, a szállítási feladatok végrehajtására nem lehet igénybe venni, például a javításban lévő eszközállomány.

\section{6. ábra: Áruszállító jármúvek csoportosítása, üzemi állapotuk szerint}

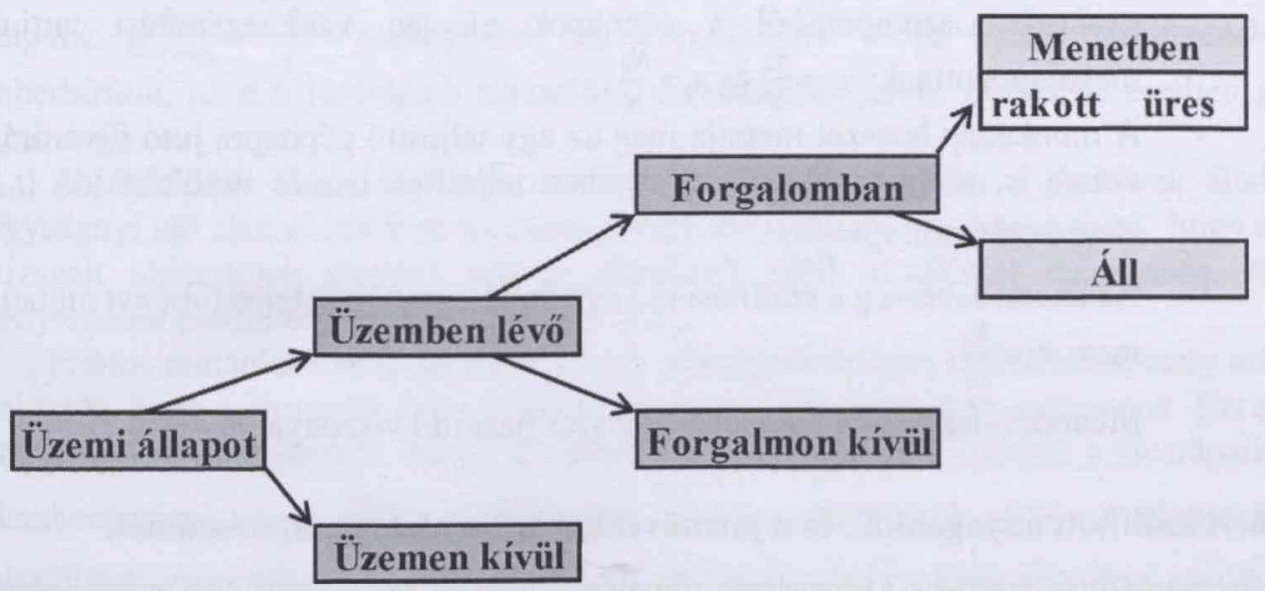

Forrás: Saját szerkesztés

Az üzemben lévő járműveket tovább csoportosíthatjuk forgalomban lévő és forgalmon kívüli állományra. A forgalomban lévő állomány tényleges szállítási feladatot lát el, míg a forgalmon kívüli eszköz, fuvarhiány vagy egyéb más okból várakozik.

A forgalomban lévő eszközöket, egy adott vizsgált időpontban további két csoportba sorolhatjuk, a szerint, hogy ténylegesen menetet (rakottan, vagy üresen) hajtanak-e végre, vagy állnak.

A közúti áruszállítás üzemi és szolgáltatási színvonalának mérőszámainál a tehergépkocsik esetén a következő teljesítmény mutatókat lehet használni:

- A jármüállomány futásteljesítménye tehergépkocsiknál: összes futás $\left(K_{\ddot{o}}\right)$, ezen belül rakott futás $\left(K_{r}\right)$;

- A raksúlytonna-kilométer (R), mely a jármüvek kapacitását is figyelembe vevő futásteljesítmény.

- A járművek időbeni rendelkezésre állása a gépnapok $(N)$, amelyen belül kimutatják az üzemképes $\left(N_{i i}\right)$ és a ténylegesen dolgozó $\left(N_{d}\right)$ gépnapok számát.

- Összes szállítási idő $\left(t_{s z}\right)$, ezen belül menetben töltött idő $\left(t_{m}\right)$.

- Az átlagos dinamikus teherbírás a raksúlytonna-kilométer és az összes futás hányadosa: $q_{d r}=\frac{R}{K_{\dot{o}}}$.

- $\mathrm{Az}$ átlagos statikus teherbírás az összes raksúlykapacitás és a jármủdarabszám hányadosa: $q_{s r}=\frac{C_{r}}{J}$. 
- A futás kihasználási tényező (\%) a rakott és az összes futás hányadosa: $f_{r}=\frac{K_{r}}{K_{b}}$.

- Dinamikus raksúly kihasználási tényező az árutonna-kilométer teljesítmény és a raksúlytonna-kilométer hányadosa: $h_{r}=\frac{T}{R}$.

- Az üzemképességi tényezö $\left(n_{i u}\right)$ és a teljesítési tényezö $\left(\mathrm{n}_{\mathrm{t}}\right)$ a jármüállomány idöbeni kihasználását mutatja. Számítása többféleképpen történhet, mi gyakorlati szempontból a gépnapok alapján való számítást tartjuk megalapozottnak: $n_{\dot{u}}=\frac{N_{i u}}{N}$ és $n_{t}=\frac{N_{d}}{N}$.

- A munkanap hosszát mutatja meg az egy teljesítő gépnapra jutó fuvarórák száma is, mely a vizsgált időszakban teljesített összes szállítási idő $\left(t_{s z}\right)$ alapján számol: $t_{d}=\frac{t_{s z}}{N_{d}}$.

- Az üzemi sebesség a szállítási idő egy órájára jutó futásteljesítményt mutatja meg: $v_{i u}=\frac{K_{i}}{t_{s z}}$.

- Menetidő-tényező a menetidő és a szállítási idő viszonya: $m=\frac{t_{m}}{t_{s z}}$.

\section{A szállított anyagokkal, és a jármúvekkel kapcsolatos mutatószámok}

Az elszállított árukhoz kapcsolódó mutatószámok az elszállított áru mennyiségét jellemzik. Értelmezése kétféleképpen lehetséges. Az egyik az egy jármü által elszállított árumennyiségre, illetve az összes jármü által elszállított mennyiségre vonatkozik a vizsgált időszakban. Az árumennyiséget tömeg- és térfogategységben fejezhetjük ki. Így beszélhetünk árutömegröl (mértékegysége: árutonna $/ \mathrm{t} /$ ) és árutérfogatról (mértékegysége: áruköbméter $/ \mathrm{m}^{3} \%$.

Az elszállított áru mennyisége mellett a jármü által megtett távolsággal is jellemezhetjük a teljesítményt. A megtett távolság alatt a jármüvek helyváltoztatása során megtett út kilométerben kifejezett hosszát értjük. A megtett távolságot útnak értelmezzük, amely az eszköz által megtett távolság, a kiindulási hely és a célállomás között.

A jármüpark darabszáma (a jármüpark természetes mutatószáma alatt) alatt azokat a számadatokat értjük, amelyeket a jármüvek, illetve azok mennyiségi jellemzőinek összegzésével kapunk. A jármüpark darabszáma az adott időpillanatban, vagy időegység alatt átlagosan a vállalat állományában lévő eszközök darabszáma.

A szervezetek (a vállalatok) fontos mutatója a jármüvek-, illetve a jármüparkok szállítókapacitása. $\mathrm{Az}$ áruszállító jármüvek szállítókapacitását a raksúly, a hordképesség, a raktérfogat, illetve az árubefogadó képesség alapján jellemezhetjük. A jármüpark szállítókapacitását a raktömegre vonatkozólag, a jármüvek darabszámának és azok hordképességének szorzatából kapjuk: $Q_{e l m}=G_{\ddot{u}} \times q=$ tonna, ahol a $G_{u ̈}$ a jármüpark (igénybevételre kerülö) üzemképes jármüveinek darabszáma, a $\mathrm{q}$ az igénybevételre tervezett jármüvek raktömege 
(tonna), a $Q_{e l m}$ a jármüparkkal elméletileg elszállítható maximális mennyiséget mutatja meg.

Ha több féle teherbírású jármüve van a vállalatnak, akkor ezt a számítást jármü típusonként kell elvégezni, majd az úgy kapott eredmények összegéből kapjuk meg a vállalat jármüveinek hordképességét. Ha a vállalatnak minden típusú és hordképességü jármüvéböl ugyanannyi van, akkor a számítást a jármüvek átlag szállítókapacitásával is elvégezhetünk, amit a jármüvek teherbírásának átlagából kapunk $Q_{n \text { elm }}=\frac{\sum q_{n}}{n}=$ tonna, ahol $q_{n}$ a jármüpark n-dik típusú jármủvének teherbírását, az n a jármüpark típusainak darabszámát jelöli. Ebben az esetben a $Q_{\text {elm }}=Q_{n \text { elm }}$.

A jármüpark által elszállított mennyiséget megkapjuk, ha a jármüvek által egységnyi idő alatt elszállított árumennyiséget összegezzük, így megkapjuk, hogy a vizsgált időszakban mennyi volt a jármüpark által elszállított mennyiség. A ténylegesen elszállított mennyiség jele a $Q_{\text {tény }}$.

Fontos mutatószámnak minősül az egy jármüpark átlagos terhelése is, mely azt fejezi ki, hogy a jármủvek futás közben átlagosan hány tonna árut szállítottak. Ezt a mutatószámot megkapjuk, ha az elszállított árumennyiséget elosztjuk a jármüpark

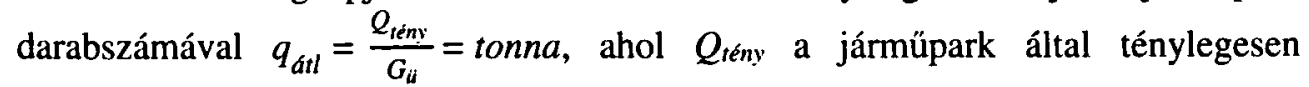
elszállított árumennyiség, $G_{u}$ a vizsgált időszakban üzemeltetett gépjármüvek száma, az így kapott eredmény a qătl a járművek átlagos terhelése a vizsgált időszakban.

Összefüggésben megállapítható, hogy a vállalat a szállítókapacitásának minél nagyobb arányú kihasználásával javíthatja a teljesítményét. Ennek mérésére a kapacitás kihasználási indexet alkalmazzuk. A kapacitás kihasználási index megmutatja, hogy a ténylegesen elért eredménnyel, milyen mértékben használtuk ki a rendelkezésre álló kapacitásunkat. A következő egyenletben az éta jelöli a kapacitás kihasználási indexet: $\eta=\frac{Q_{\text {tény }}}{Q_{e l m}} \times 100$. Emellett fontos a jármüvek költségjellemzője is és a tevékenységek során felhasznált üzemanyag értéke. A költségek kalkulációjánál figyelembe vesszük a jármü fogyasztási normáját, amelyböl kiszámolható a várhatóan felhasználásra kerülő üzemanyag értéke is.

\section{Teljesítménymutatók alkalmazása a közúti szállításban}

A teljesítménymutatók alkalmazása azért is fontos a vállalkozások esetében, mivel ez szoros kapcsolatban áll a versenyképességgel, míg a korábban taglalt hatékonysági mutatók csak a müködést jellemzik. Véleményünk szerint a teljesítménymutatók használatával egy jobb müködés irányozható elö. Mivel, ha valami hatékony, attól még az nem lesz versenyképes is, de ha valami versenyképes (kiváló teljesítménymutató) nem biztos, hogy hatékony is. Ezért is tartjuk fontosnak, hogy az átfutási idővel, illetve a minőséggel kapcsolatos mutatókat is tekintsük át.

Ha a vállalatok elmulasztják mérni logisztikai teljesítményeiket, még abban sem lehetnek biztosak, hogy miért nyereségesek, vagy miért veszteségesek, és miben jobbak, vagy rosszabbak, mint versenytársaik. Mivel nem tudják magukat tárgyilagosan összehasonlítani más vállalatokkal, fogyasztóik elvárásaival vagy a 
nyilvánosságra hozott ipari átlagokkal, a tények ismerete nélkül kell a vállalat irányítását végezniük (Oláh, 2016; Oláh et al., 2017).

$\mathrm{Az}$ átfutási idővel kapcsolatos mutatók a szállítási átfutási idő, a szállítási gyorsaság, illetve a rugalmasság. Az átfutási idő nagyságát a szállításoknál előforduló késések befolyásolják legnagyobb részben.

A mindennapi használatban lévő szállítási idő nem egyezik meg a szállítási átfutási idővel. A szállítási idő a megrendelés eladó általi kézhezvételétől az áru vevő általi átvételig terjed. Ezen kifejezésbe beletartozik a megrendelés feldolgozása, a komissiózás, a rakomány rögzítése, valamint az áru berakodása, szállítása és kirakodása a célállomáson. Ezzel ellentétben a szállítás átfutási ideje az az átfutási idő, ami ahhoz szükséges, hogy egy cikk eljusson a szállító féltől a fogadó félhez.

A szállítási átfutási időnél figyelembe kell venni az egységrakomány-képzés és bontás idejét (minden fokozatban), a rakodási időket (minden átrakóhelyen), az egységrakományok tárolási idejét, a szállítási időket (minden szállítási feladatra), illetve az egyéb járulékos időket szállítás-nemenként.

A szállítási gyorsaság alatt azt érjük, hogy a kiinduló ponttól a végállomásig mennyi idő telik el. Természetesen a gyorsaság mellett figyelni kell arra is, hogy sérülésmentesen jusson el a termék a kezdő ponttól a végpontig.

A szállítás rugalmassága a harmadik eleme az átfutási idővel kapcsolatos mutatóknak. A szállítás rugalmassága megmutatja, hogy az eladó rendszere lehetővé teszi-e, hogy különleges vevőigényeket is figyelembe vegyenek, vagy a vevő szállítói logisztikájának az elosztási logisztika szigorú szabályait kell-e követnie. Mindent összevetve a szállítás rugalmassága három befolyásoló tényezőtől függ: a megrendelési folyamattól, a szállítási folyamatoktól és a vevő által adott információktól (Oláh et al., 2016).

A másik csoportot a minőséggel kapcsolatos mutatók alkotják, melybe a szállítási minőség és a szállítási megbízhatóság tartozik.

A szállítási minőséggel mérhető, hogy a vevő milyen mértékben kifogásolhatja magát a szállítást. A szállítás minősége két tényezőtől függ. Az egyik a szállítás pontossága, másik a küldemény állapota. A szállítás pontossága megmutatja, hogy a megrendelt termékek leszállítása a kért összetételben és mennyiségben történik-e. A küldemény állapota elsősorban attól függ, hogy a csomagolás mennyire tölti be védö funkcióját az áru leszállítása során. Egy termék vagy áru akkor tekinthető az adott szerződésben foglaltak szerint leszállítottnak, ha az áru lényegében megegyezik a termékleírásban foglaltakkal. Lehetőség van kisebb eltérésekre is, mely a termék állagát, állapotát nem befolyásolja. Eltérés lehet az áru vastagsága, szakítószilárdsága, színárnyalata és enyvezettsége esetén.

A második minöséggel kapcsolatos mutatónk a szállítás megbízhatósága (a szállítási célok és ütemezés betartása), mely azt fejezi ki, hogy mekkora a valószínüsége annak, hogy sikerül betartani a szállítási időt. A szállítás megbízhatósága függ a munkafolyamat megbízhatóságától és a szállítási készségtől. A szállítási idő egyes szakaszaiban zajló munkafolyamatokat ütemezés szerint kell végrehajtani, az elöre meghatározott időkereten belül. A szállítási készség megmutatja, milyen mértékben szállítható a kért mennyiség. 
A felsorolt mutatók képzése általános formában:

$$
V_{i} \%=1-\frac{\text { Hibás szállítások száma }}{\ddot{O}_{\text {sszes } \text { szállítás }}} \cdot 100
$$

A hibás szállítás lehet nem megfelelő időben érkezett szállítás, nem megfelelő minöségben teljesített szállítás stb. A mutatók képezhetök vállalati szinten, de gépjármü, illetve gépjármüvezető bontásban is. A nagyobb vállalkozások esetén a napi gyakorlatban az alapadatok rendelkezésre állnak, és gyakori a gépjármüvezetők bérezésébe történő beépülés is, viszont vevőkiszolgálási színvonal értékelésére viszonylag ritkábban használják. Az alapmutatókból összetett értékelési rendszer építhető pontozásos, vagy egyéb súlyozási módszerek segítségével. A szállítás teljesítményértékelésében még nem terjedt el, de hasznos lehet a mutatók alapján a statisztikai folyamatelemzés alkalmazása is, mert ezzel lehetőség nyílik a hibák és a káros folyamatok idöben történő hatékony kezelésére.

Összességében megállapítható, hogy pozitív a kapcsolat a szállitási gyorsaság és megbizhatóság között, azaz a jelenlegi vállalati környezetben, az időalapú versenyben a vevő mind a gyorsaságot, mind a megbízhatóságot elvárja egyidejüleg (Morash et al., 1996).

\section{Következtetés}

$\mathrm{Az}$ anyagban összesített mutatószámok segítségével könnyebben lehet megoldani az egyes vállalatoknál a fuvarok összehangolását, illetve a hatékonyabb müködést. A mutatószámok alkalmazásával a szervezeteknek lehetősége nyilik a sarkalatos pontok javítására, illetve a vetélytársakkal való versenyképességet jobban tudják kontrolálni. A tanulmány alapján összesíthető, hogy egy szállítás megszervezése esetében fontos a rövid szállítási idő biztosítása, a jó szállítási minőség, a szállítási készenlét, a szállítási megbízhatóság és a szállítási rugalmasság.

\section{Irodalomjegyzék}

Halászné Sipos E. (1998): Logisztika (szolgáltatások, versenyképesség). Magyar Világ Kiado, Budapest.

Körmendi L., Pucsek J. (2008): A logisztika elmélete és gyakorlata. SALDO Kiadó, Budapest

Morash, E. A., Dröge, C., Vickery, S. (1996): Boundary spanning interfaces between logistics, production, marketing and new product development. Published by MCB UP Ltd. (C MCB UP Limited.

Oláh J. (2016): A raktári szolgáltatások minőségi mutatói. International Journal of Engineering and Management Sciences, Müszaki és Menedzsment Tudományi Közlemények. 1 (1): 1-10. <http://ijems.lib.unideb.hu/file/9/57696440b3a65/szerzo/Olah_-_A_RAKTaRI _SZOLGaLTATaSOK_MINoSeGI_MUTAToI.docx>

Oláh J., Balogh P., Lakner Z., Popp J.(2016): Alapanyag-készlet csökkentésére irányuló folyamatok bemutatása az ellátási láncban. Információs Társadalom, 16 (4): 61. May 2017 DOI: 10.22503/inftars.XVI.2016.4.4 License: CC BY-NC-ND 4.0.

Oláh J., Harangi-Rákos M., Popp J. (2017): Innovative Development of Warehouse Technology. Network Intelligence Studies (2/2017), 5 (10): 107-1 16. <http://nis.bxb.ro/2017-10-nis-volumev-issue-2/> 